\title{
Intestinal spirochetosis and colon diverticulosis
}

\author{
Espiroquetose intestinal e diverticulose do cólon
}

\author{
Marcus Aurelho de Lima ${ }^{1,2}$, André Luís Barbosa ${ }^{1,2}$, Vitorino Modesto dos Santos², \\ and Felipe Prata Misiara ${ }^{2}$
}

\begin{abstract}
A case of intestinal spirochetosis in a 62-year-old white male is reported. The condition was characterized by chronic flatulence and episodes of intestinal hemorrhage, in addition to the evidence of hypotonic diverticular disease, with a large number of slender organisms in the colon epithelium and cryptae. Spirochetes were demonstrated by WhartinStarry stain. The serologic tests for syphilis and HIV were positive. Spirochetosis was treated with penicillin G, and the patient remains free of intestinal complaints 20 months later.
\end{abstract}

Key-words: Colon. Diverticulosis. HIV. Intestinal bleeding. Spirochetosis.

\section{RESUM0}

Um caso de espiroquetose intestinal é relatado em um homem branco de 62 anos. A condição foi caracterizada por flatulência crônica e episódios de hemorragia intestinal, além da evidência de doença diverticular hipotônica dos cólons, com numerosos organismos filamentosos no epitélio e nas criptas do cólon. Os espiroquetas foram demonstrados pela coloração de Whartin-Starry. Os testes sorológicos para sífilis e HIV foram positivos. A espiroquetose foi tratada com penicilina $\mathrm{G}$ e 0 paciente permanece sem queixas intestinais após 20 meses.

Palavras-chaves: Cólon. Diverticulose. Espiroquetose. HIV. Sangramento intestinal.

We report a case of intestinal spirochetosis associated with colon diverticular disease and HIV infection. Although colorectal spirochetosis was described in humans by Harland and $\mathrm{Lee}^{2}$ in 1967, there still remains some controversy about clinical significance and its association with diarrhea and intestinal bleeding ${ }^{356}$. Here, the first cases were reported by De Brito et al ${ }^{1}$. This condition has been scarcely reported, and is characterized by the histological appearance of a false brush border on the colonic mucosa, which represents a layer of spirochetes ${ }^{2}$, especially Brachyspira aalborgi and Brachyspira pilosicoli (Serpulina pilosicoli) ${ }^{5}$. Spirochetes presumably result from fecaloral contamination, and the colonization rate in human colon depends upon sanitation conditions, diet, sexual practices, and immune function ${ }^{6}$. Although the association of intestinal spirochetosis with human immunodeficiency virus infection could favor invasive disease, dissemination to other organs is extremely rare ${ }^{6}$.

Our purpose is to emphasize unsuspected spirochetosis as a possible diagnostic pitfall in patients presenting intestinal bleeding associated or not with diverticulosis.

\section{CASE REPORT}

A 62-year-old white male was seen on July 2002, with a chronic complaint of flatulence and episodes of intestinal hemorrhage that occurred only during evacuation. The patient used alcohol and tobacco occasionally, but denied drug abuse and there was no history of homosexuality. He was non-febrile and in a good general state. The heart was normal; pulse rate, $80 \mathrm{bpm}$; blood pressure, 140/80 mmHg. The lungs, liver, arterial pulses, and lymph nodes were normal. The spleen was not palpable. A tender lower left abdominal quadrant was found during palpation. Stool examinations revealed no conventional pathogens. A full blood count and biochemistry determinations were normal. Proctologic examination disclosed hemorrhoids at 3 and 7 hours, without other changes on anuscopy. Colonoscopy showed pan-colon hypotonic diverticular disease, and biopsy samples were obtained from the colon. Histological examination of the colon biopsies showed mucosa surface covered with a large number of filamentous bacilli (Figure 1)

1. Cancer Combat Association of Central Brazil, Uberaba, MG; 2. University Hospital of Triângulo Mineiro Medical School, Uberaba, MG, Brazil. Address to: Prof. Marcus Aurelho de Lima. Disciplina de Endocrinologia/CM/FMTM. Getúlio Guaritá 130, Abadia 38025-440 Uberaba-MG, Brazil. Tel: 55343318 5258, Fax: 553433126640.

e-mail:lima@mednet.com.br.

Recebido para publicação em 6/8/2004

Aceito em 17/9/2004 
stained with silver-methenamine by Whartin-Starry method (Figure 2). Additionally, there were edema, moderate inflammatory infiltrate of lymphocytes and numerous eosinophils in the corium. After the histopathological data, the serologic tests for syphilis and HIV were positive. Spirochetosis was treated with penicillin $\mathrm{G}$, and the patient is found free of intestinal complaints 20 months later.

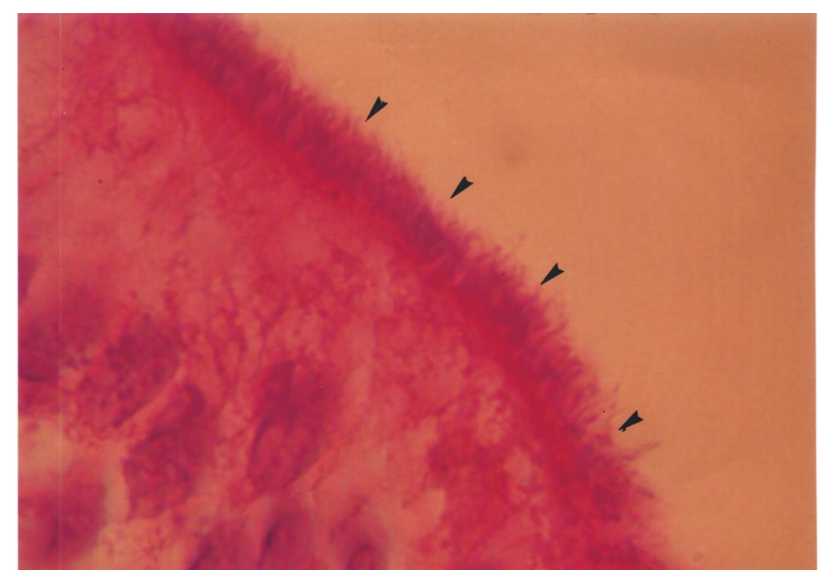

Figure 1 - Detail of colon epithelium with numerous slender bacilli adhered to the mucosa surface (arrowheads) (HE x 400).

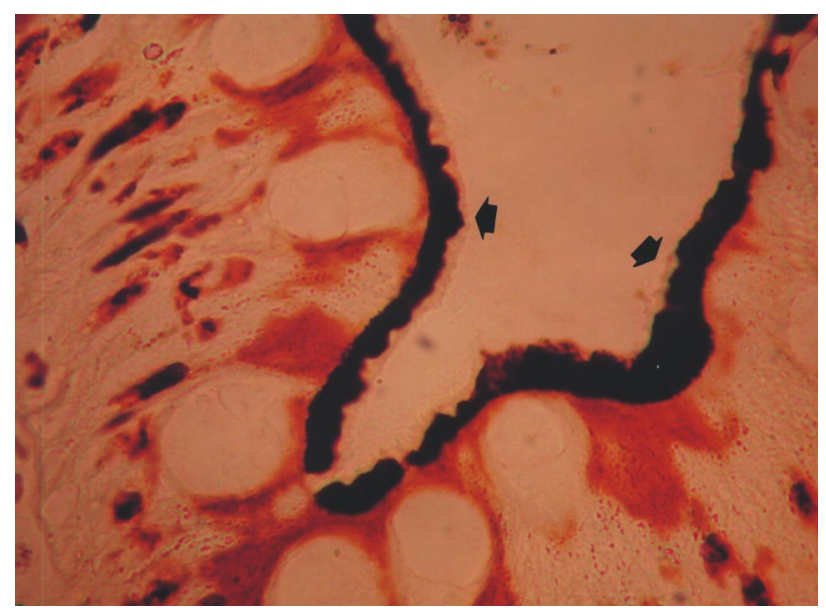

Figure 2 - The spirochetes appear in colon mucosa stained by silvermethenamine (arrows) (Whartin-Starry $x$ 400).

\section{DISCUSSION}

This patient presented with bright intestinal bleeding, similarly to several other reports ${ }^{3}$. Although the exact source of bleeding could not be established through endoscopic examination, the colon diverticular disease could play a role in this case. The diagnosis of intestinal spirochetosis was established by the histologic study of colon biopsy ${ }^{12345678910}$.

In spite of the apparent response to penicillin $G$, with resolution of his symptoms ${ }^{4.9}$, we could not entirely ascertain the absence of other eventual pathogens associated with HIV infection ${ }^{5}$. Notwithstanding, the patient had no vomiting, abdominal pain, diarrhea, or loss of weight, the most frequent complaints were after intestinal opportunistic infections.
Moreover, the study of biopsy allowed us to identify the infectious process and the spirochetes, which are not detected in the routine stool examinations ${ }^{8}$. It is noteworthy that spirochetes are difficult to grow on culture media, which is an important limitation for their characterization in clinical practice. In addition to immunohistochemistry ${ }^{1}$, the best way to identify spirochetes includes ultrastructural study ${ }^{14}$ and polymerase chain reaction ${ }^{10}$, sophisticated tools are not easily available. In this context, the positive test for syphilis could constitute another index of suspicion for general practitioners. Based on clinical suspicion, the diagnosis of intestinal spirochetosis could be confirmed without additional costs, because spirochetes are easily identified through silvermethenamine stain. However, Orenstein and Dieterich (2001) found only four cases of spirochetosis in colon biopsies from 82 symptomatic patients with acquired immunodeficiency syndrome ${ }^{8}$ and conclude that treatable conditions may be overlooked by less experienced surgical pathologists.

Although we cannot discard the hypothesis that diverticulosis may favor the colonization of spirochetes, independently from the patient's immune function, in this case the evidence of intestinal spirochetosis allowed the suspicion of concomitant HIV infection.

We suggest the inclusion of spirochetosis in the differential diagnosis of intestinal bleeding occurring in patients with or without changes at colonoscopy, and biopsy specimens could be obtained in order to favor the correct diagnosis in such cases.

\section{REFERENCES}

1. De Brito T, Sandoval MP, Silva AG, Saad RC, Colaiacovo W. Intestinal spirochetosis: first cases reported in Brazil and the use of immunohistochemistry as an aid in histopathological diagnosis. Revista do Instituto de Medicina Tropical de São Paulo 38: 45-53, 1996.

2. Harland WA, Lee FD. Intestinal spirochaetosis. British Medical Journal 3:718-719, 1967.

3. Heine RG, Ward PB, Mikoska AS, Bennett-Wood V, Robins-Browne RM, Hampson DJ. Brachyspira aalborgi infection in four Australian children. Journal of Gastroenterology and Hepatology 16:872-875, 2001.

4. Korner M, Gebbers J0. Clinical significance of human intestinal spirochetosis - a morphologic approach. Infection 31:341-349, 2003.

5. Macaignel G, David F, Boivin J-F, Cheiab S, Chayette C, Deplus R. Spirochétose colo-rectale, une cause possible mais inhabituelle de diarrhée chronique? Presse Medicale 31:458-461, 2002.

6. Marthinsen L, Willén R, Carlén B, Lindberg E, Värendh G. Intestinal spirochetosis in eight pediatric patients from Southern Sweden. Acta Pathologica, Microbiologica, et Immunologica Scandinavica 110:571-579, 2002.

7. Nakamura S, Kuroda T, Sugai T, Ono S, Yoshida T, Akasaka I, Nakashima F, Sasou S. The first reported case of intestinal spirochetosis in Japan. Pathology International 48:58-62, 1998.

8. Orenstein JM, Dieterich DT. The histopathology of 103 consecutive colonoscopy biopsies from 82 symptomatic patients with acquired immunodeficiency syndrome: original and look-back diagnosis. Archives of Pathology and Laboratory Medicine 125:1042-1046, 2001.

9. Peghini PL, Guccion JG, Sharma A. Improvement of chronic diarrhea after treatment for intestinal spirochetosis. Digestive Diseases and Sciences 45:1006-1010, 2000.

10. Shah RN, Stosor V, Badve S. Colon biopsy in a patient with diarrhea Possible etiologic agent. Archives of Pathology and Laboratory Medicine 125:699-670, 2001. 